\title{
Engineering Design and Feasibility Analysis of Geothermal-heated Swimming Pool in Lembang, West Java
}

Allen Haryanto Lukmana ${ }^{1 *}$, Rizqi Mahfudz Prasetyo ${ }^{1}$, Ria Ayu Rifani ${ }^{1}$

${ }^{1}$ Department of Petroleum Engineering, Faculty of Mineral Technology, Universitas Pembangunan Nasional Veteran Yogyakarta, SWK No 104 (North Ring Road) Condongcatur, Sleman, Special Region of Yogyakarta, Indonesia 55283

"Corresponding Author: allenharyanto@upnyk.ac.id

\begin{tabular}{|c|c|}
\hline Article History: & Abstract \\
\hline $\begin{array}{l}\text { Received: November 19, } 2019 \\
\text { Receive in Revised Form: July 10, } 2020 \\
\text { Accepted: July 14, } 2020\end{array}$ & \multirow{3}{*}{$\begin{array}{l}\text { A heated swimming pool has long been known as a tourist } \\
\text { destination, sports, to stress therapy. Warm water is obtained from } \\
\text { burning fuels such as fossil fuel that is not environmentally friendly. } \\
\text { Then technologies based on an alternative energy source is needed } \\
\text { to be an optimal solution to the heating of a swimming pool, which } \\
\text { can be very expensive in terms of energy demand and environment } \\
\text { conservation. Due to the sizeable geothermal potential owned by } \\
\text { Indonesia and only } 3 \% \text { of the total potential that has been } \\
\text { successfully used for electricity generation (PLTP), therefore a design } \\
\text { of a heated swimming pool heated by geothermal fluid was made to } \\
\text { utilize clean and environmentally friendly energy sources in the } \\
\text { Lembang region, West Java. The pool, which is designed to have an } \\
\text { area of } 10 \times 10 \mathrm{~m}^{2} \text {, has a temperature of } 26-30^{\circ} \mathrm{C} \text { and is heated by } \\
\text { a geothermal fluid at a rate of } 12.71 / \mathrm{s} \text { and a temperature of } 110^{\circ} \mathrm{C} \text {. } \\
\text { The total heat energy utilized is } 170 \text { to } 330 \mathrm{~W} / \mathrm{m}^{2} \text {. Economic analysis } \\
\text { shows an NPV of more than one and an IRR of } 17 \% \text { for a } 10 \text {-year } \\
\text { economic life. Hence, this warm swimming pool deserves to be } \\
\text { developed. }\end{array}$} \\
\hline Keywords: & \\
\hline $\begin{array}{l}\text { Geothermal Direct Use, Swimming Pool, } \\
\text { Heat Transfer, Heat Pool, Warm Pool, } \\
\text { Economic Analysis, Lembang, LMTD, } \\
\text { Engineering Design }\end{array}$ & \\
\hline
\end{tabular}

\section{INTRODUCTION}

Indonesia has a geothermal potential of around $29 \mathrm{GWe}$ which is dominated by wet steam reservoir fluids (Darma, 2016). At present only $807 \mathrm{MW}(3 \%)$ of the total potential has been successfully utilized for electricity generation (PLTP). Thus, there are still many potential geothermal resources that cannot be utilized either for electricity or non-electricity purposes (BPPT, 2004). In the past, people warmed water using firewood under a pond. Over time, firewood is substituted by heaters that use fossil energy. The latest development in the water health sector is a bathing facility that uses geothermal water from wells (Orkustofnun, 2020).

Heating of swimming pools constitutes an energy consumable procedure. So far, most swimming pools are heated using liquid fossil fuels, mainly diesel oil, burnt in conventional diesel oil burners. However, the continuously rising fossil fuel prices during the last decade led to considerable increase of the swimming pool's heating cost. The high energy consumption in swimming pools presents an attractive challenge but also significant opportunities for energy conversion (Barbato et al., 2018).

The perspective of the swimming pools' heating using renewable energy sources systems, appeared caused by pure economic parameters, and is further strengthened by the generally recognized necessity for the reduction of the fossil fuels' global consumption, imposed by the available reserves exhaustion and environmental protection reasons.

Gathering the above economic, energy saving and environment conservation terms, it is justified that, maybe more than ever, the introduction of alternative swimming pools' heating technologies, based on cheap and abundant renewable energy sources emerges as an imperative necessity, on the one hand, and, on the other, as a redemptive solution. 
In this research, process of heating water in a swimming pool will be done using a geothermal energy source. This is in line with the policy of using alternative energy as a substitute for fossil energy that is non-renewable and can damage the surrounding environment.

\section{METHODOLOGY}

In designing a warm swimming pool that is heated by a geothermal source, it must be known several desired conditions in the system from the pool of warm water. This is summarized in the Table 1.

Table 1. Parameters for designing a heated swimming pool

\begin{tabular}{ll}
\hline Pool Parameters & Value \\
\hline Swimming Pool Dimension & Surface: $10 \times 10 \mathrm{~m}^{2}$ \\
Depth of Swimming Pool (assumption) & For Children : 0.5 meter $\rightarrow$ Surface area: $30 \mathrm{~m}^{2}$ \\
& For Adult $: 1.5$ meter $\rightarrow 70 \mathrm{~m}^{2}$ \\
Pool temperature required & $26-30^{\circ} \mathrm{C}$ \\
Wind speed & Max $1 \mathrm{~m} / \mathrm{s}$ per year \\
Distance from geothermal source & $200 \mathrm{~m}$ \\
Elevation of geothermal source & $-10 \mathrm{~m}($ pump required) \\
Brine temperature & $110^{\circ} \mathrm{C}$ \\
Brine Pressure & $2 \mathrm{bara}$ \\
Brine Mass flow & $12.62 \mathrm{~kg} / \mathrm{s}$ \\
\hline
\end{tabular}

\section{Size of Swimming Pool}

Based on Fahmy et al. (2014), the size of a pool of warm water can be formulated as follows:

$$
V=L W \frac{d_{\min }+d_{\max }}{2}
$$

Where $\mathrm{V}$ is Volume of water $\left(\mathrm{m}^{3}\right), \mathrm{L}$ is Length swimming pool $(\mathrm{m}), \mathrm{W}$ is Wide swimming pool $(\mathrm{m}), \mathrm{d}_{\text {min }}$, $\mathrm{d}_{\max }$ is Pool depth range $(\mathrm{m})$. In this study, there is one swimming pool which has an area of $10 \mathrm{x} 10 \mathrm{~m}^{2}$. This swimming pool is for children and adults and it is assumed that the depth of the children's zone is $0.5 \mathrm{~m}$ and adults are $1.5 \mathrm{~m}$. The shallow depth for this swimming pool is $0.25 \mathrm{~m}$. Table 2 shows the calculation of the volume of water for children and adult part. Design of a heated swimming pool presented in Figure 1.

Table 2. Calculation of warm water pool volume

\begin{tabular}{ccccc}
\hline Pool section & Length $(\mathrm{L})$ & Wide $(W)$ & $\mathrm{d}_{\min } \& \mathrm{~d}_{\max }$ & Volume \\
\hline Children's & $10 \mathrm{~m}$ & $3 \mathrm{~m}$ & $(0.25 \& 0.5) \mathrm{m}$ & $11.25 \mathrm{~m}^{3}$ \\
Adult & $10 \mathrm{~m}$ & $7 \mathrm{~m}$ & $(0.25 \& 1.5) \mathrm{m}$ & $61.25 \mathrm{~m}^{3}$
\end{tabular}

Based on calculations, total water volume needed for bathing areas for children and adults is $72.5 \mathrm{~m}^{3}$.

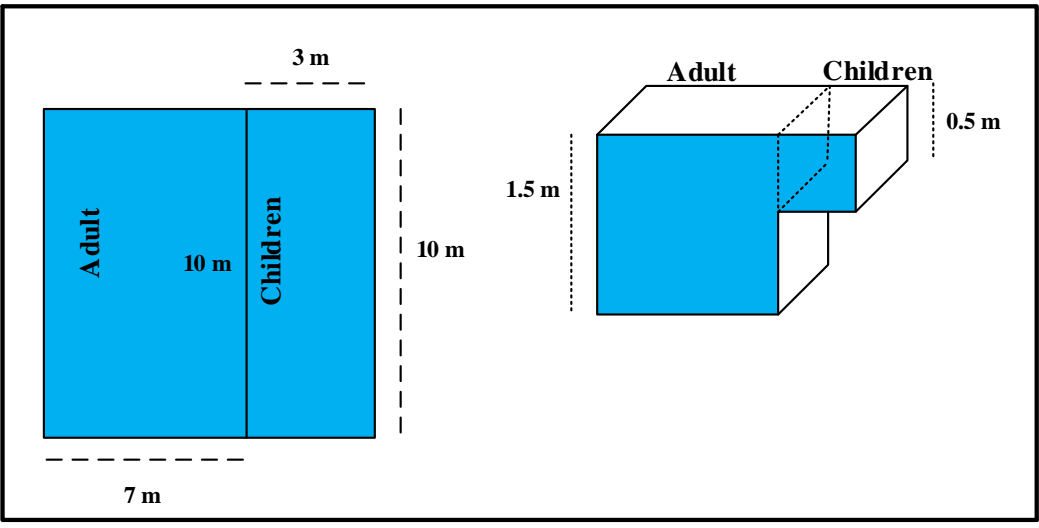

Figure 1. Visualization design of heated swimming pool 


\section{Warm Water Swimming Pool Working System}

Working mechanism of the warm water swimming pool system is designed to meet the user's sanitation and comfort needs. In addition, design of a heated swimming pool is also used to minimize energy consumption heating water and chemical quantities used to clean the pool. It aims to maintain the cleanliness of water, bacteria that damage the skin and maintain water temperature as needed, which is around $26-30{ }^{\circ} \mathrm{C}$.

Geothermal fluid from production well as shown in Figure 2 will flow into a heat exchanger with a pump, due to the difference in distance of $200 \mathrm{~m}$ and elevation of $10 \mathrm{~m}$ between the geothermal source and the warm water swimming pool area. The heat exchanger used is a brazed plate heat exchanger, to transfer heat from geothermal fluid with cold fluid circulating in the warm water pool system.

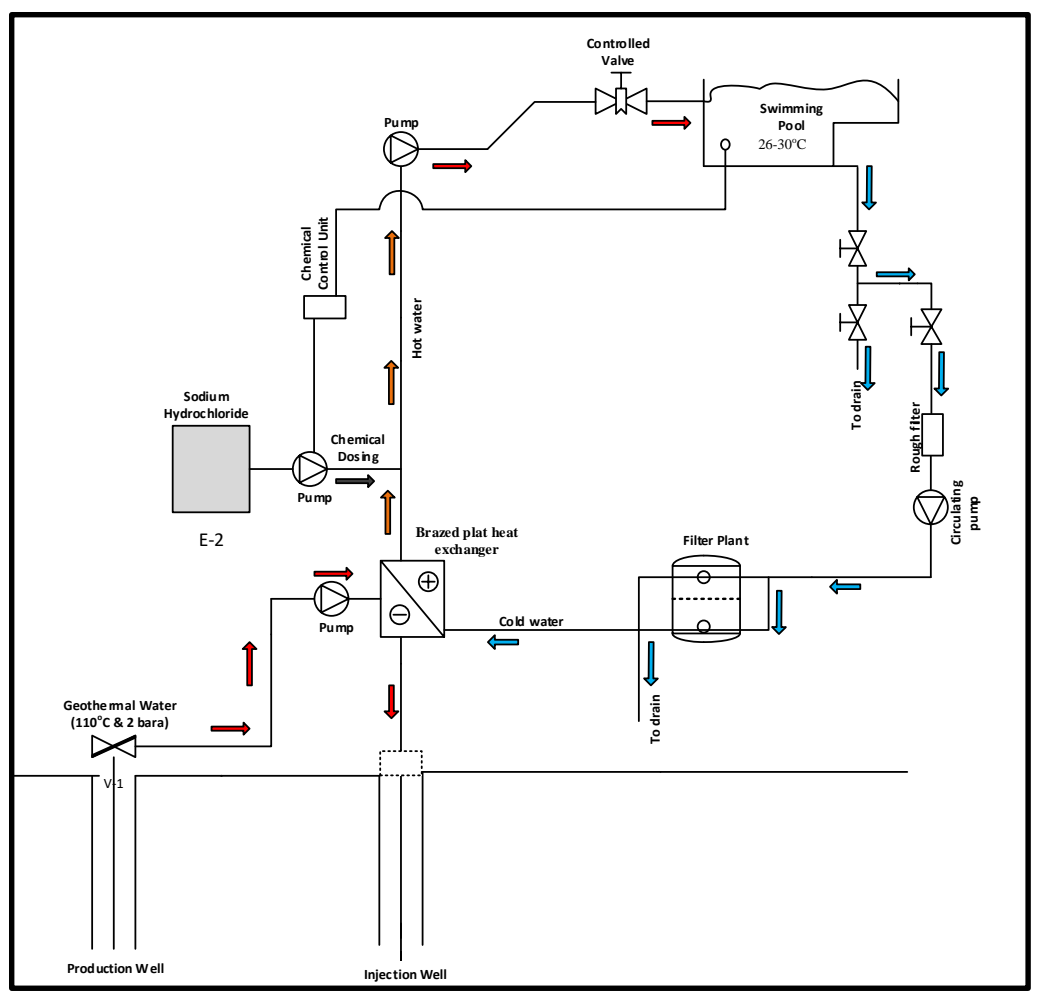

Figure 2. Schematic diagram of a heated swimming pool

This heated swimming pool system uses chemicals to maintain the cleanliness of the pool from bacteria. Chemical used in this system is sodium hydrochloride, known as a chemical for cleaning swimming pools. Chlorine is highly effective in removing bacteria, viruses, and algae in swimming pools. Sodium hydrochloride can dissolve easily in water and work quickly to clean water, if added a little ozone will cause the water to become cleaner and sparkling.

As shown in Figure 2, chemicals are pumped into hot water channels from the heat exchanger. The quantity of chemicals pumped is controlled by chemical controlling unit which is sensitive with $\mathrm{pH}$ value of the fluid in heated pool. When $\mathrm{pH}$ value is below set condition, the control unit will give a signal to pump inject chemicals and will stop when pool fluid $\mathrm{pH}$ is above the set value. Fluid temperatures in warm water pools are expected to be at $26-30^{\circ} \mathrm{C}$ and this value must be maintained by considering the condition of outdoor swimming pools with an average ambient temperature assumed to be $21^{\circ} \mathrm{C}$.

Water circulation in this system is very influential in maintaining fluid temperature and cleanliness. Water circulation in the warm water pool system is influenced by the period of time between the fluid entering the pool to exit the pool, through a pipe that has been designed. In this study the turnover period is set every 1.5 hours.

Swimming pool water cleanliness will also be supported by the installation of filter plants in which there is sand and gravel. The mechanism in the filter plant is to pass dirty fluid from the pool into the sand and gravel. This method will simply filter out the impurities that are suspended in the fluid. In this system also installed a temperature control that the temperature sensor will be installed in the pool. When the pool temperature is below the setting point, the regulator at the head of the production well will open and drain 
the geothermal fluid into the heat exchanger. The required rate of geothermal fluid flow is very dependent on the fluid heat loss in the warm water pool.

\section{Swimming Pool Piping System}

The development of a swimming pool area cannot be separated from the piping system, which allows fluid to flow from one point to another (Van Everdingen \& Hurst, 1949). Choosing pipe material is one of the key factors to maintain water quality in a swimming pool area. In this study, warm water is the main parameter that has a fairly aggressive nature to the surrounding environment. All types of pipes made from polypropylene (PP) or polyethylene (PVC) have passed the hot water flow test, which is in accordance with this study. These pipes will be installed on the swimming pool floor as a hot water circulation site.

The previous chapter explained that circulation of water in heated swimming pool very dependent on turnover period and the amount of mass flowed (Omotayo Adewale \& Sunday, 2015). Turnover period assumed in this study is 1.5 hours and mass flowed is volume of the pool itself. Volume of the swimming pool is based on calculations of $72.5 \mathrm{~m}^{3}$ from the adult and children's sections. Calculation of mass flow rate to fill a hot water pool can use the following formulation (Ahmed, 2018):

$$
m=\frac{V}{T_{o}}
$$

Where $\mathrm{V}$ is the water volume $\left(\mathrm{m}^{3}\right)$ and $\mathrm{T}_{\mathrm{o}}$ is the turnover period (hours). Based on the formula above, we can calculate the mass flow rate for the children's part, which is $2 \mathrm{~L} / \mathrm{s}$, and for adult, $11.34 \mathrm{~L} / \mathrm{s}$, so that the total mass flow rate that must be flowed in a heated swimming pool is equal to $13.34 \mathrm{~L} / \mathrm{s}$.

The design pool pipeline itself by installing a number of inlet nozzles at the bottom of the pool, mass flow rate for each nozzle can be calculated by:

$$
m_{\text {in }}=\frac{m}{n_{o}}
$$

Where $M_{\text {in }}$ is Mass flow rate passes through each nozzle; (L/s), no is Number of nozzles in each section. With this formulation, mass flow rate for each nozzle in the children is equal to $\min =2 / 15 \approx 0.1 \mathrm{~L} / \mathrm{s}$ and for adult's $\min =11.34 / 25 \approx 0.5 \mathrm{~L} / \mathrm{s}$.

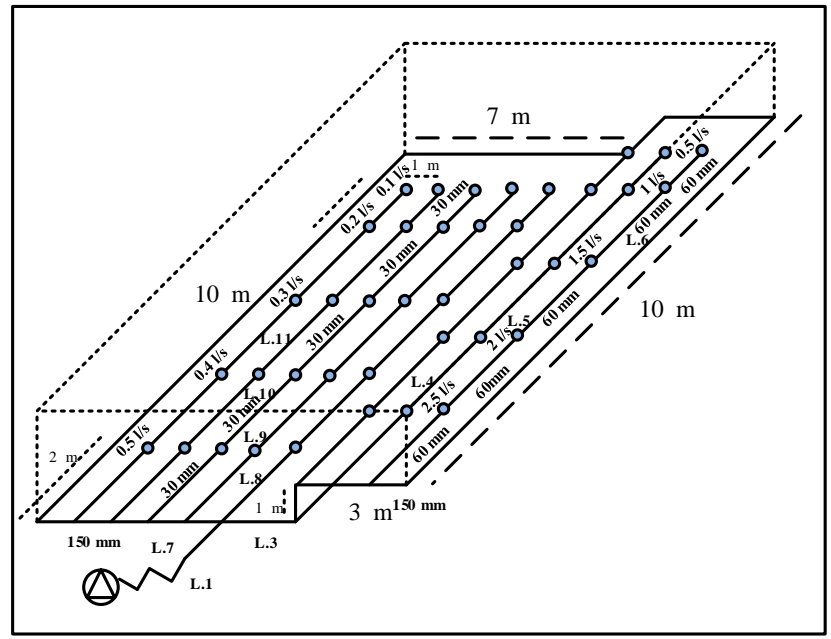

Figure 3. Overview layout piping of heated swimming pool

Piping design as shown in Figure 3, is obtained from the pressure drop calculation based on the calculation of mass flow rate that comes out for each nozzle. Water distribution channels in pool, depend on the size of the pipe installed. Pipes installed at the bottom of the pool have several varied sizes, namely $30 \mathrm{~mm}$ for the adult section and $60 \mathrm{~mm}$ for the children's section. Difference in the size of the pipe to get an even distribution of water in the pond.

\section{Drop Pressure Calculation and Pump Type Selection}

Calculation of pressure drop in hot water pool system is very influential on heat exchanger type, filter plant, length and pipe mechanism used (Carter \& Tracy, 1960). Besides that, pressure and temperature are important components in the calculation of pressure drop. Length, diameter, and type of pipe used in this study can determine the pressure drop, especially piping design as shown in Figure 3. Type of pipe 
used in this study is PVC pipes have specifications of pressure drop values to the diameter and length of the pipe and the speed of fluid flowing in the pipe. The basis for calculating the pressure drop is formulated (Ahmed, 2018) as follows.

$$
\Delta P=\frac{\rho v^{2}}{2} \frac{f L}{2}
$$

$\Delta \mathrm{P}$ is Pressure drop $(\mathrm{kPa}), \mathrm{f}$ is friction factor, $\rho$ is Fluid density $(\mathrm{kg} / \mathrm{m} 3), \mathrm{v}$ is fluid velocity $(\mathrm{m} / \mathrm{s}), \mathrm{L}$ is Length pipe $(\mathrm{m}), \mathrm{D}$ is Diameter $(\mathrm{m})$. The friction factor can be calculated using the following equation.

$$
f=\frac{1}{\left(2 \log \frac{D}{2 K}+1.74^{2}\right)}
$$

$\mathrm{K}$ is Pipe roughness factor.

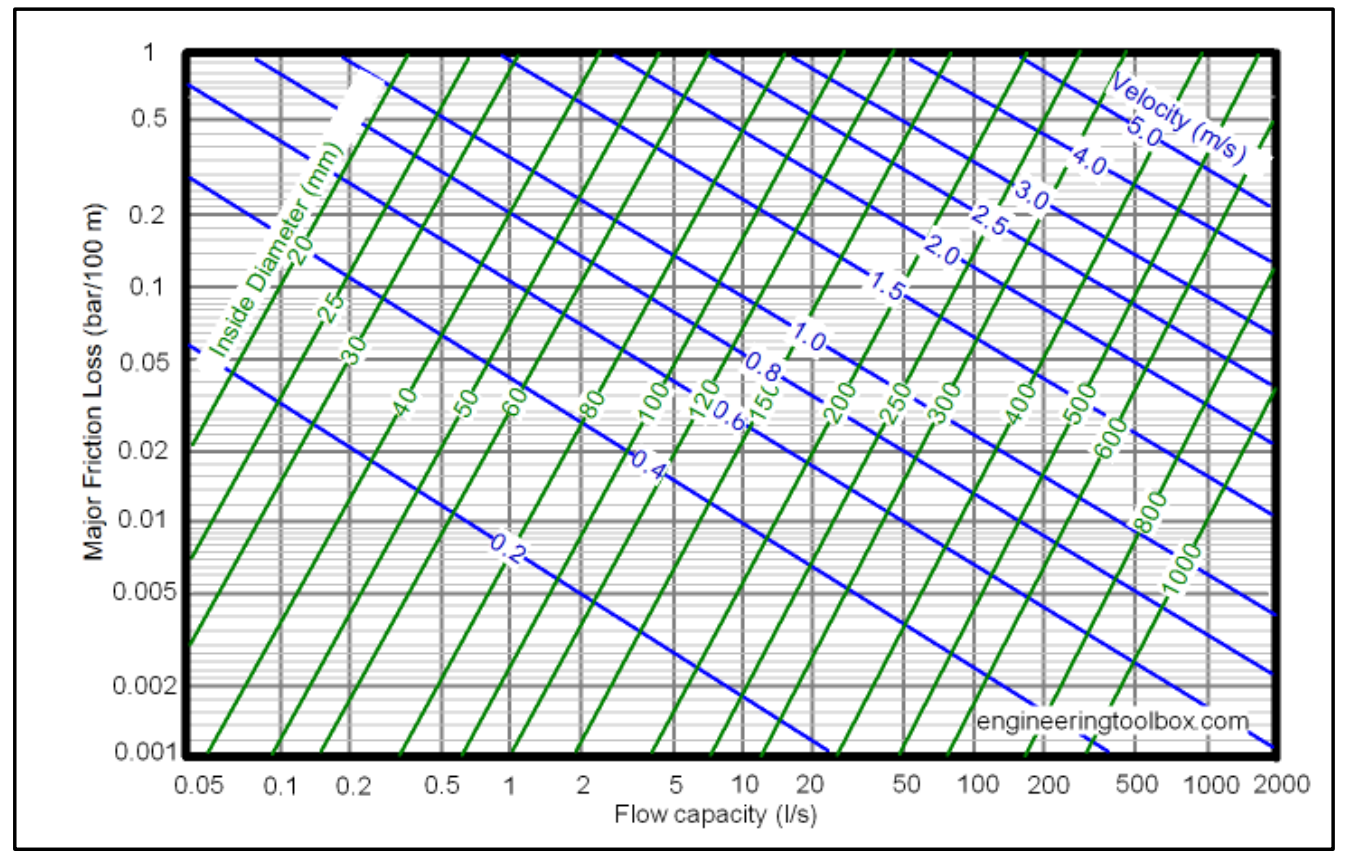

Figure 4. Calculation of pressure drop for PVC material types (Sources: (Engineering ToolBox, 2003)

Calculation of pressure drop in pipe can be approached using the graph in Figure 4. Determination of pressure drop can be done based on mass flow rate parameters for each line, that has been described in Figure 3. The mass flow rate at the bottom of the pond is divided into two lines that lead to children's and adult pools. The total pressure drop calculations for pipes at the bottom of the pond are shown in the Table 3 and Table 4 below:

\begin{tabular}{|c|c|c|c|c|c|}
\hline Velocity $(\mathrm{m} / \mathrm{s})$ & Flow rate $(\mathrm{L} / \mathrm{s})$ & Length $(\mathrm{m})$ & Pipe Diameter $(\mathrm{m})$ & $\mathrm{dP} / 100 \mathrm{~m}$ & $\mathrm{dP}($ bara $) / \mathrm{m}$ \\
\hline 0.1 & 0.1 & 1 & 0.03 & 0.02 & 0.0002 \\
\hline 0.3 & 0.2 & 2 & 0.03 & 0.05 & 0.001 \\
\hline 0.5 & 0.3 & 2 & 0.03 & 0.15 & 0.003 \\
\hline 0.6 & 0.4 & 2 & 0.03 & 0.18 & 0.0036 \\
\hline 1 & 0.5 & 2 & 0.03 & 0.3 & 0.006 \\
\hline \multicolumn{5}{|c|}{ Total for $\mathrm{L} 8+\mathrm{L} 9+\mathrm{L} 10+\mathrm{L} 11$} & 0.0552 \\
\hline 1.5 & 13.4 & 1 & 0.1 & 0.4 & 0.004 \\
\hline 0.6 & 6.7 & 5 & 0.1 & 0.05 & 0.0005 \\
\hline \multicolumn{5}{|c|}{ Total for L1+L7 } & 0.0045 \\
\hline \multicolumn{6}{|c|}{ Pressure drop in the system from pool to pump in Line A } \\
\hline 1.5 & 13.4 & 15 & 0.1 & 0.4 & 0.06 \\
\hline \multicolumn{5}{|c|}{ Total Pressure drop Line A } & 0.12 \\
\hline
\end{tabular}

Table 3. Pressure drop calculation for line A consisting of L1, L7, L8, L9, L10, and L11 
Table 4. Pressure drop calculation for line B consisting of L1, L3, L4, L5, and L6

\begin{tabular}{|c|c|c|c|c|c|}
\hline Velocity $(\mathrm{m} / \mathrm{s})$ & Flow rate $(\mathrm{L} / \mathrm{s})$ & Length $(\mathrm{m})$ & Pipe Diameter $(\mathrm{m})$ & $\mathrm{dP} / 100 \mathrm{~m}$ & $\mathrm{dP}($ bara $) / \mathrm{m}$ \\
\hline 0.2 & 0.5 & 1 & 0.06 & 0.01 & 0.0001 \\
\hline 0.4 & 1 & 2 & 0.06 & 0.03 & 0.0006 \\
\hline 0.5 & 1.5 & 2 & 0.06 & 0.05 & 0.001 \\
\hline 0.7 & 2 & 2 & 0.06 & 0.1 & 0.002 \\
\hline 1.1 & 2.5 & 2 & 0.06 & 0.3 & 0.006 \\
\hline \multicolumn{5}{|c|}{ Total for $\mathrm{L} 4+\mathrm{L} 5+\mathrm{L} 6$} & 0.0291 \\
\hline 1.5 & 0.004 & 1 & 0.1 & 0.4 & 0.004 \\
\hline 0.6 & 0.0005 & 5 & 0.1 & 0.05 & 0.0005 \\
\hline \multicolumn{5}{|c|}{ Total for $\mathrm{L} 1+\mathrm{L} 3$} & 0.0045 \\
\hline \multicolumn{6}{|c|}{ Pressure drop in the system from pool to pump in Line B } \\
\hline 1.5 & 13.4 & 15 & 0.1 & 0.4 & 0.06 \\
\hline \multicolumn{5}{|c|}{ Total Pressure drop Line B } & 0.0936 \\
\hline
\end{tabular}

Based on the calculations described in Table 3 and Table 4, total pressure drop from pipe network at the bottom of pool is 0.2 bara. Pressure drop for the heat exchanger is based on the information specifications of brazed plate heat exchanger product presented in Table 5. Swimming pool capacity in this study is 72.5 $\mathrm{m}$ or 20,000 gallons, so the heat exchanger specification that is given a red line is used. Pressure drop heat exchanger based on that data is $\approx 4$ psi or 0.3 bar.

Table 5. Data specifications for the Taco Hv-Ac brand for use as a pool heating media

\begin{tabular}{|c|c|c|c|c|c|c|}
\hline \multirow{3}{*}{$\begin{array}{l}\text { Pool } \\
\text { Capacity }\end{array}$} & \multicolumn{3}{|c|}{$1 \mathrm{degF} / \mathrm{Hr}$ Heat Up Rate } & \multicolumn{3}{|c|}{2 degF/Hr Heat Up Rate } \\
\hline & Boiler Output & Boiler Side & & Boiler Output & Boiler Pump & \\
\hline & Required & Minimum & TACO Model & Required & Minimum & TACO Model \\
\hline (Gallons) & (BTUH) & GPM & & (BTUH) & GPM & \\
\hline 8,000 & 66,760 & 4 & TMP5x12-8 (1"MPT) & 133,520 & 9 & TMP5x12-10 (1 "MPT) \\
\hline 10,000 & 83,450 & 6 & TMP5x12-8 (1"MPT) & 166,900 & 11 & TMP5x12-16 (1"MPT) \\
\hline 12,000 & 100,140 & 7 & TMP5x12-10 (1"MPT) & 200,280 & 13 & TMP5x12-16 (1"MPT) \\
\hline 15,000 & 125,175 & 8 & TMP5x12-10 (1 "MPT) & 250,350 & 17 & TMP5x12-20 (1 1/4"MPT) \\
\hline 20,000 & 166,900 & 11 & TMP5x12-16 (1 "MPT) & 333,800 & 22 & TMP5x12-24 (1 1/4"MPT) \\
\hline 25,000 & 208,625 & 14 & TMP5x12-16 (1 "MPT) & 417,250 & 28 & TMP5x12-30 (1 1/4"MPT) \\
\hline 30,000 & 250,350 & 17 & TMP5x12-20 (1 1/4"MPT) & 500,700 & 33 & TMP5x12-40 (1 1/4"MPT) \\
\hline
\end{tabular}

The selection of sand filter plant with bold text, is based on the total needs of fluid circulation to be flowed into the swimming pool. In this study, a laser sand filter system produced by Jacuzzi company is used as a sand filter plant. The type used is L225 which can filter water at a flow rate of $25 \mathrm{GPM} / \mathrm{ft}^{2}$ or about 15 $\mathrm{L} / \mathrm{s}$ (matches circulation at a flow rate of $13.4 \mathrm{~L} / \mathrm{s}$ ). The amount of sand needed for this process is $113 \mathrm{~kg}$. The energy needed to filter by type L225 is 69 watts. The technical specifications of the LN 225 filter can be explained in Figure 5. 
Engineering Design and Feasibility Analysis of Geothermal-heated Swimming Pool in Lembang, West Java (A H Lukmana, R M Prasetyo, R A Rifani)

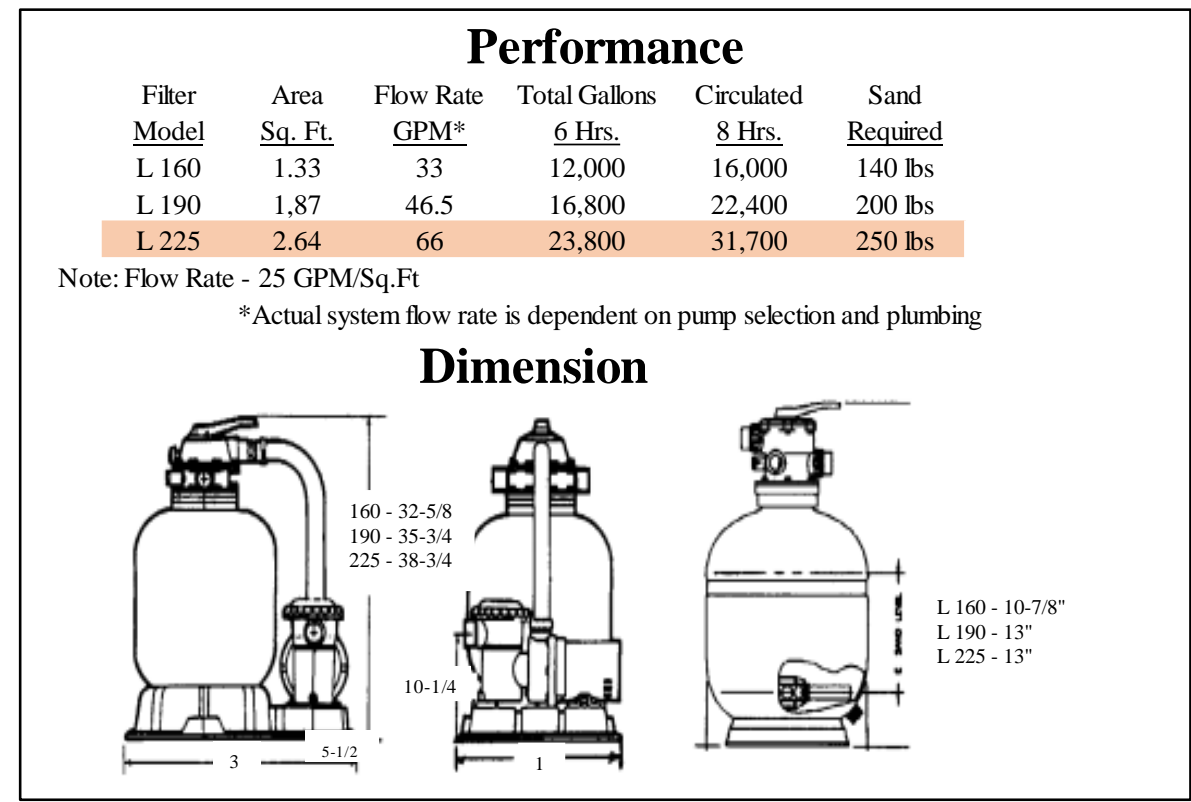

Figure 5. Sand filter performance of LN 225 Jacuzzi model (source: Jacuzzi (2005))

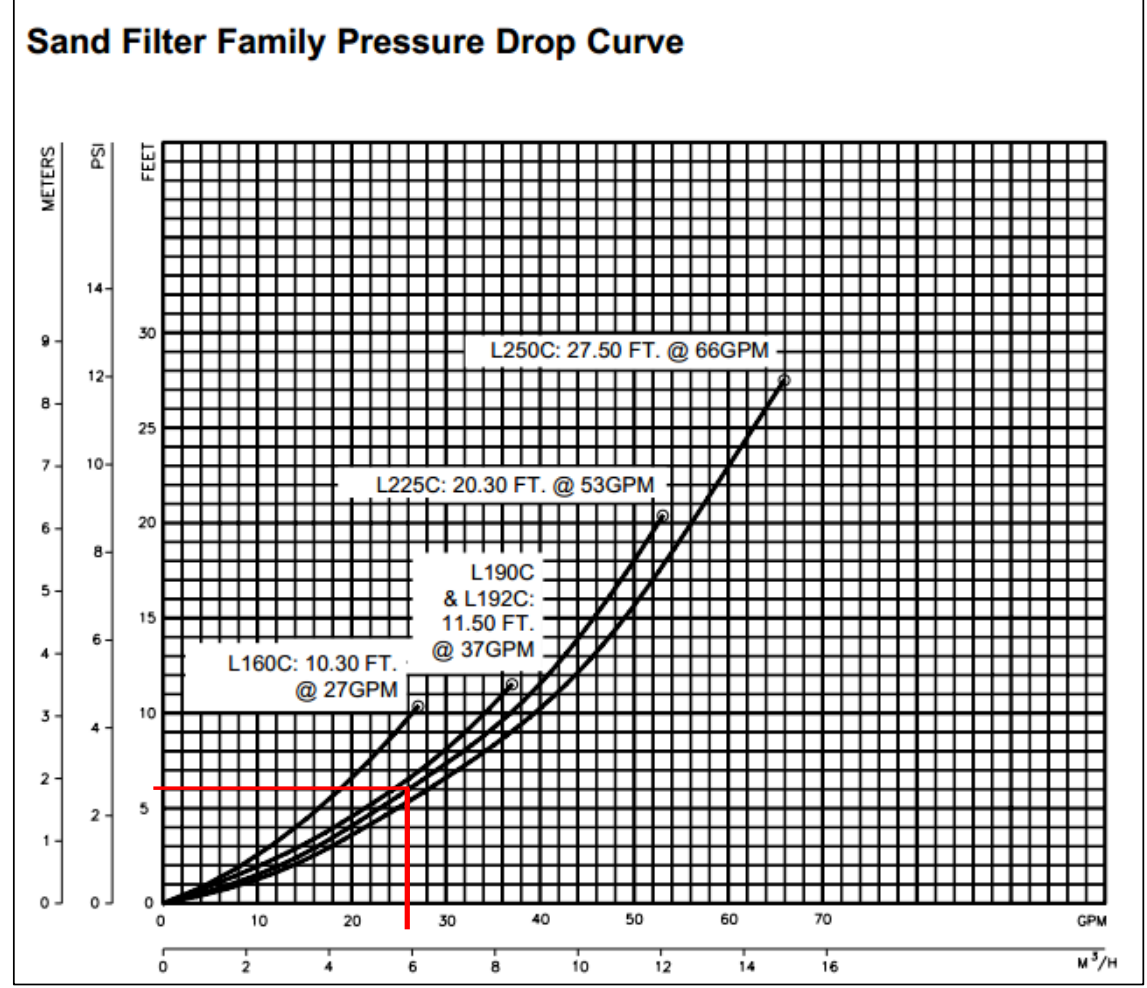

Figure 6. Filter performance LN 225 Jacuzzi (source: Jacuzzi (2005))

Pressure drop for the filter can be calculated based on the data in Figure 6. and to drain as much as 25 GPM of water the pressure drops in the filter is $\approx 7$ psi or 0.5 ember. The total pressure drop in this system can be tabulated as follows:

- $\quad$ Pressure drop for heat exchangers is 0.3 bar.

- $\quad$ Pressure drop for the filter plant is 0.5 bar.

- The height of the swimming pool is $1.5 \mathrm{~m}$ and $0.5 \mathrm{~m}$ so that the pressure drop can be calculated at 0.2 bar.

- $\quad$ Pressure drop during the water flow in the pipe at the bottom of the pond has been considered based on a major loss of 0.2 bar. 
The total pressure drop for the system is 1.3 bar and the total mass flow rate is $13.4 \mathrm{~L} / \mathrm{s}$. The pump component in the pool system mechanism is influenced by the total mass flow rate and pressure drop then there is a safety margin of $20 \%$. In this study an internet study was conducted to obtain the type of circulating pump suitable for this mechanism. We select pump products from Afton pump company with the product specifications described in the following (Table 6, Figure 7).

Table 6. Product specifications for Afton pump

\begin{tabular}{lc}
\hline Properties & Value \\
\hline Type and size & ILVS 4x6 -9L \\
Rotational speed (rpm) & 1170 \\
Head (m) & 5.5 \\
Efficiency at specified flow rate & $71.2 \%$ \\
NPSH required by pump manufacturer at specif. flow rate $(\mathrm{m})$ & $0.5 \mathrm{~m}$ \\
Power (HP) & 1.35 \\
\hline
\end{tabular}

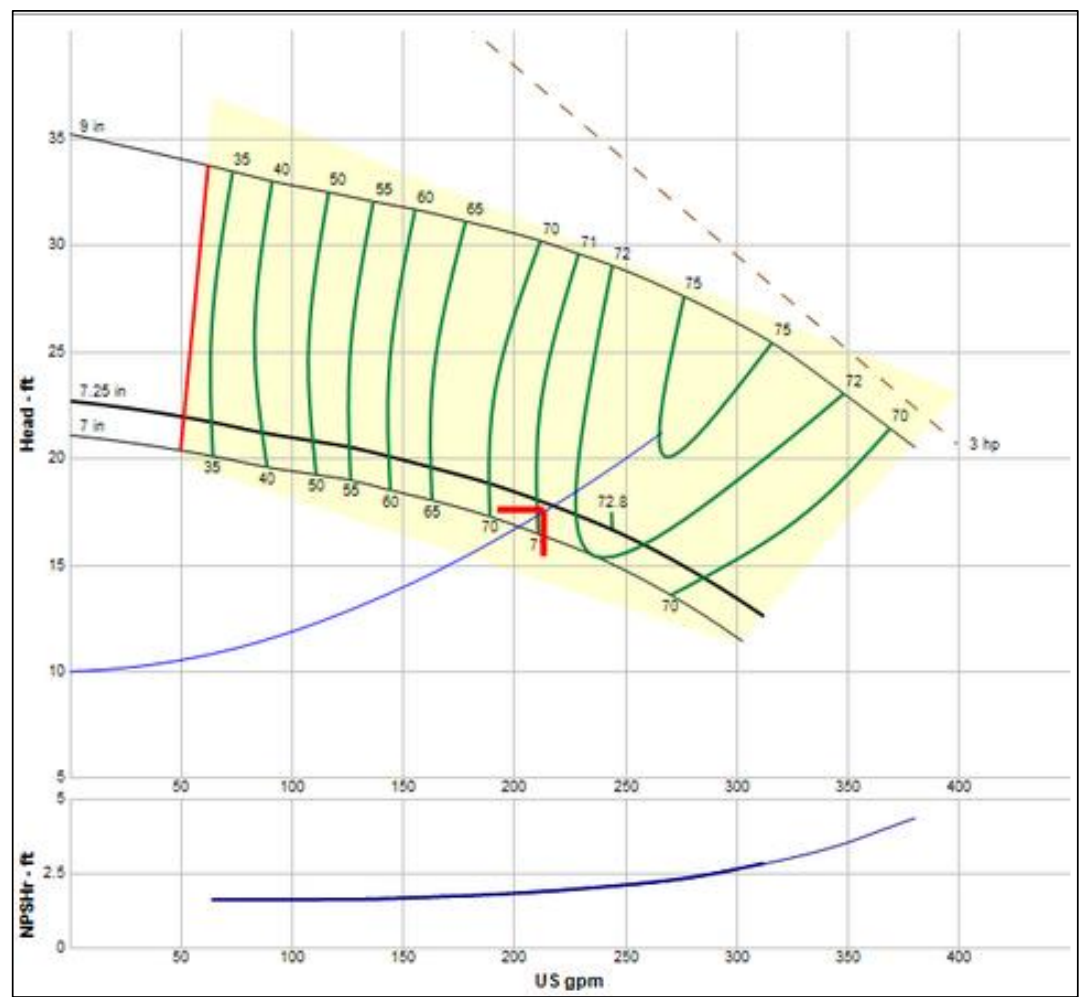

Figure 7. Pump selection curve for swimming pool (source: https://www.storefronts.pump-flo.com/storefronts)

\section{RESULT AND DISCUSSION}

\section{Energy Required for Heating}

In designing a hot pool system, heat loss is one of the most important parameters to get the desired pool temperature. In this study, the heated swimming pool is assumed to be located in an area around the city of Lembang, West Java. Based on data from wisatalembang.com, the average air temperature in this area is between $17^{\circ} \mathrm{C}$ to $25^{\circ} \mathrm{C}$ and the average airspeed of this area is $1 \mathrm{~m} / \mathrm{s}$.

Figure 8 shows a flowchart of heat transfer from a geothermal source to a heated swimming pool. According to Svavarsson (1990), heat loss in an outdoor hot tub depends on convection, evaporation, radiation, conduction, and rain, but the major heat loss in a heated swimming pool is affected by convection and evaporation. Other factors such as conduction, radiation and rainwater can usually be estimated to be equal to $10 \%$ of heat loss convection and evaporation (Jalili Nasrabadi, 2004). 
Based on the flow diagram in Figure 8, geothermal fluid with a mass flow rate of $12.7 \mathrm{~L} / \mathrm{s}$ and a temperature of $110^{\circ} \mathrm{C}$ flows towards the heat exchanger with a distance of $\approx 200 \mathrm{~m}$ and has an elevation of $-10 \mathrm{~m}$ so that elevation difference between geothermal source and swimming pool area is $10 \mathrm{~m}$ so it needs a pump to draw the fluid. Heat transfer that occurs between the point of the geothermal source to the entry point of the heat exchanger is dominated by conduction and convection processes.

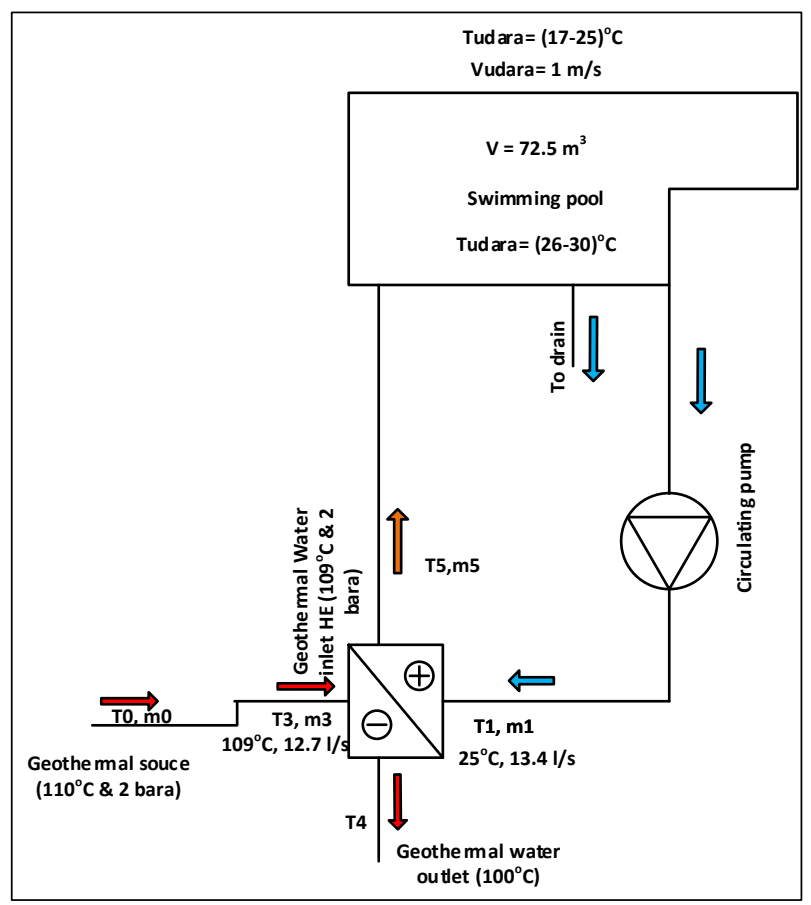

Figure 8 . Heat and mass flow diagram for a heated swimming pool

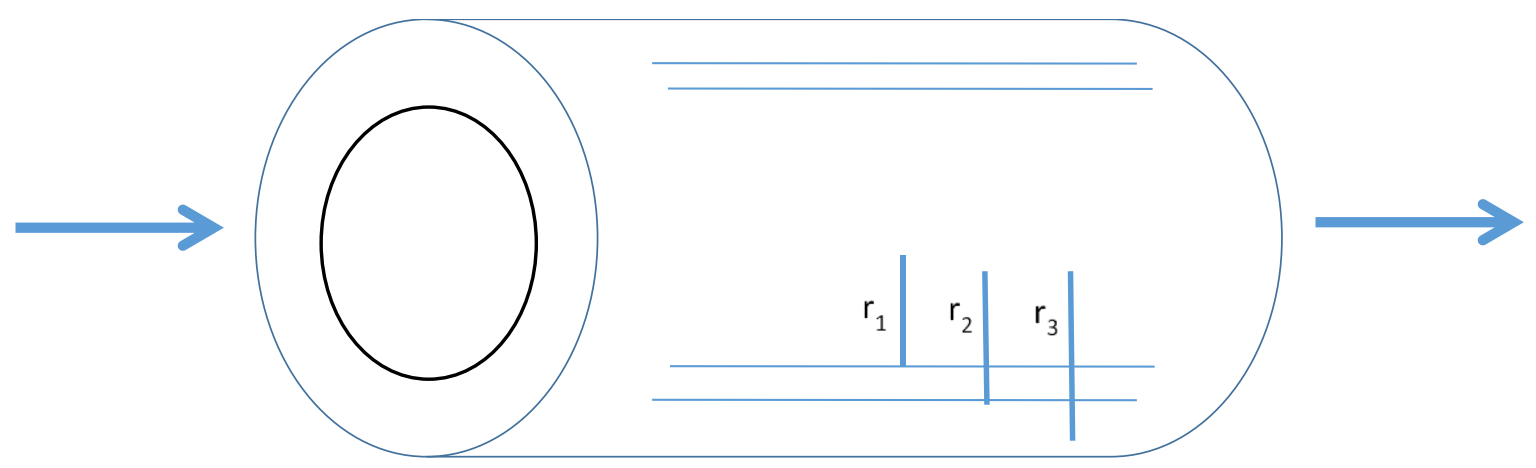

Figure 9. Heat transfer scheme from the point of geothermal source up to the inlet point

Convection heat transfer in pipe is shown in Figure 9. It occurs between outside air to outer wall and from inner wall to air inside the pipe. The conduction process occurs between the outer wall and the inner wall. The formulation for the phenomenon can be calculated as follows:

$$
\begin{gathered}
Q_{\text {convection }}=h A\left(T_{\sim}-T_{1}\right) \\
Q_{\text {conduction }}=k A\left(T_{1}-T_{2}\right) \\
Q_{\text {convection }}=h A\left(T_{2}-T_{\text {fluida }}\right)
\end{gathered}
$$

Where Q is heat loss $(\mathrm{J} / \mathrm{s}), \mathrm{h}$ is heat transfer coefficient by convection $\left(\mathrm{W} / \mathrm{m}^{2} . \mathrm{K}\right), \mathrm{k}$ is coefficient of heat transfer by conduction $(\mathrm{W} / \mathrm{mK})$, and $\mathrm{T}$ is temperature. Rate of heat loss along pipe can be calculated using $\mathrm{U}$ (overall heat transfer coefficient) which has principle heat transfer between substances there is a resistance and is usually symbolized by an Rekivalen. Rate of heat loss can be formulated as follows:

$$
Q_{\text {loss }}=U A\left(T_{\text {inside }}-T_{\text {outside }}\right)
$$


Where $U$ is Overall heat transfer coefficient. Based on the formulation described earlier, it can be determined type of pipe and insulation material used to obtain temperature at the outlet as much as possible, describe in Table 7.

Table 7. Calculation of heat loss from geothermal sources to the heat exchanger inlet point

\begin{tabular}{lccc}
\hline Known parameters (design) & Parameter & Value & Unit \\
\hline Inlet temperature & $\mathrm{T}_{\text {in }}$ & 110 & ${ }^{\circ} \mathrm{C}$ \\
Distance between heat source and HE & $\mathrm{L}$ & 200 & meter \\
Expected outlet temperature (assumption) & $\mathrm{T}_{\text {out }}$ & 109 & ${ }^{\circ} \mathrm{C}$ \\
Fluid convection coefficient & $\mathrm{h}_{\text {fluida }}$ & 3.371 & $\mathrm{~W} / \mathrm{m}^{2} . \mathrm{K}$ \\
Conduction coefficient (stainless steel assumption) & $\mathrm{h}_{\text {stainless steel }}$ & 16.93 & $\mathrm{~W} / \mathrm{m} . \mathrm{K}$ \\
Conduction coefficient (fiberglass) & h $_{\text {fiberglass }}$ & 0.035 & $\mathrm{~W} / \mathrm{m} . \mathrm{K}$ \\
Air convection coefficient & $\mathrm{h}_{\text {air }}$ & 9 & $\mathrm{~W} / \mathrm{m}^{2} . \mathrm{K}$ \\
& & & \\
Stainless steel diameter & & & \\
Fiberglass diameter & $\mathrm{D}_{\text {stainless steel }}$ & 16 & $\mathrm{~cm}$ \\
Q along $200 \mathrm{~m}$ & D $_{\text {fiber glass }}$ & 0.6 & $\mathrm{~cm}$ \\
\hline
\end{tabular}

The heat loss in heat exchanger is influenced by temperature and mass of fluid passing through it. In this study, type of heat exchanger used is a brazed plate heat exchanger consisting of two plates and combined into one plate by pressing (Fahmy et al., 2014). Calculating the heat loss in a type of heat exchanger can use the following formulation:

$$
Q_{\text {loss }}=U \times A \times L M T D \times C_{f}
$$

Where $Q$ is heat loss $(\mathrm{J} / \mathrm{s}), \mathrm{U}$ is overall heat transfer coefficient, $\mathrm{A}$ is heat transfer area in the heat exchanger $\left(\mathrm{m}^{2}\right)$, LMTD is log mean temperature Difference, and $C_{\mathrm{f}}$ is Correction factor for LMTD (0.85-1). LMTD can be calculated based on changes in temperature between the two types of fluid that enters heat exchanger. The LMTD formulation can be described as follows:

$$
\text { Qloss }=\frac{\Delta t_{1}-\Delta t_{2}}{\ln \left(\frac{\Delta t_{1}}{\Delta t_{2}}\right)}
$$

Which $\Delta \mathrm{t}_{1}$ is $\mathrm{T}_{\text {out } 1}-\mathrm{T}_{\text {out } 2}, \Delta \mathrm{t}_{2}$ is $\mathrm{T}_{\text {in } 1}-\mathrm{T}_{\text {in } 2}$.

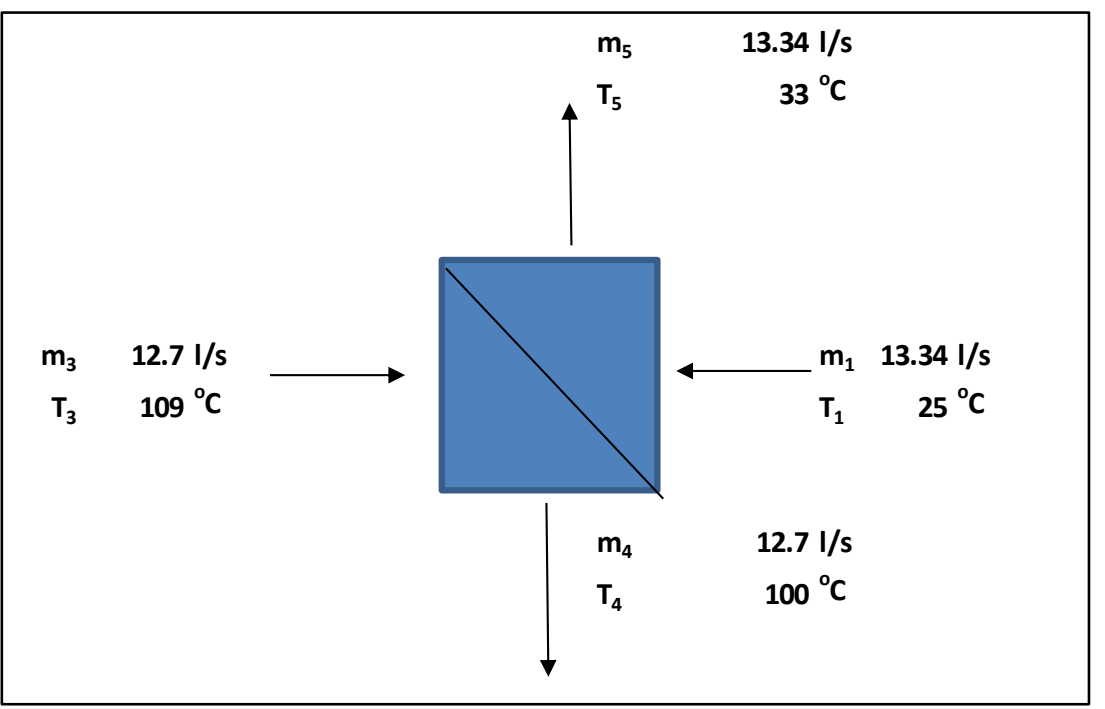

Figure 10. LMTD calculation parameters obtained from the mass and energy equation

Parameters obtained in Figure 10 are calculated based on energy and mass equations so that we can calculate the LMTD value for this heat exchanger by $75^{\circ} \mathrm{C}$. The area of heat exchanger based on industry 
data is $18 \mathrm{~m}^{2}$. Based on these calculations, an outlet temperature of heated fluid is obtained at $33{ }^{\circ} \mathrm{C}$. Previously it has been explained that for design of a heated swimming pool heat transfer process occurs by convection and evaporation. Heat loss by convection is very dependent on the temperature of the atmosphere and wind speed. The greater value of ambient air temperature and air velocity, the greater the value of heat loss in hot water pools. Heat loss by convection can be determined using Newton's law for cooling (Holman \& Rao, 1989).

$$
Q_{c}=h_{c}\left(T_{1}-T_{a}\right)
$$

Qc is heat loss by convection $\left(\mathrm{W} / \mathrm{m}^{2}\right), \mathrm{T}_{1}$ is pool fluid temperature $\left({ }^{\circ} \mathrm{C}\right), \mathrm{T}_{\mathrm{a}}$ is ambient temperature $\left({ }^{\circ} \mathrm{C}\right), \mathrm{h}_{\mathrm{c}}$ is convection heat transfer coefficient $\left(\mathrm{W} / \mathrm{m}^{2} .{ }^{\circ} \mathrm{C}\right)$. According to Svavarsson $(1990)$, the value of $\mathrm{h}_{\mathrm{c}}$ is strongly influenced by wind speed and ambient temperature and using the Rimsha-Donchenko formula:

$$
h_{c}=(K+0.45 v) 4.19
$$

Where $\mathrm{v}$ is wind speed at a height of 2 metres above ground level $(\mathrm{m} / \mathrm{s}), \mathrm{K}$ is empirical coefficient $\left(\mathrm{W} / \mathrm{m}^{2} /{ }^{\circ} \mathrm{C}\right)$; Empirical coefficients are determined based on the following equation.

$$
K=0.93+0.04\left(T_{w}-T_{a}\right)
$$

Table 8 . Variation in value of heat loss caused by convection process

\begin{tabular}{lcccccc}
\hline $\mathrm{Q}_{\mathrm{c}}\left(\mathrm{W} / \mathrm{m}^{2}\right)$ & $\mathrm{H}_{\mathrm{c}}\left(\mathrm{W} / \mathrm{m}^{2 \circ} \mathrm{C}\right)$ & $\mathrm{T}_{\text {he }}\left({ }^{\circ} \mathrm{C}\right)$ & $\mathrm{T}_{1}\left({ }^{\circ} \mathrm{C}\right)$ & $\mathrm{T}_{\mathrm{a}}\left({ }^{\circ} \mathrm{C}\right)$ & $\mathrm{K}\left(\mathrm{W} / \mathrm{m}^{20} \mathrm{C}\right)$ & $\mathrm{v}(\mathrm{m} / \mathrm{s})$ \\
\hline 14.58 & 7.29 & 33.00 & 26.00 & 24.00 & 1.29 & 1.00 \\
21.87 & 7.29 & 33.00 & 27.00 & 24.00 & 1.29 & 1.00 \\
29.16 & 7.29 & 33.00 & 28.00 & 24.00 & 1.29 & 1.00 \\
36.45 & 7.29 & 33.00 & 29.00 & 24.00 & 1.29 & 1.00 \\
43.74 & 7.29 & 33.00 & 30.00 & 24.00 & 1.29 & 1.00 \\
\hline
\end{tabular}

Table 8 shows variation in value of heat loss due to convection with a swimming pool temperature between $26-30{ }^{\circ} \mathrm{C}$ and the assumption for ambient air temperature of $24{ }^{\circ} \mathrm{C}$. Air velocity used is based on the previous assumption of $1 \mathrm{~m} / \mathrm{s}$. Heat loss caused by evaporation process is based on difference in partial pressure between water vapor on surface of the pool and the air above it. Evaporation process occurs due to loss of energy from the surface of the water. The value of heat loss can be determined using the RimshaDonchenko formulation (Jalilinasrabady et al., 2015):

$$
Q_{e}=(1.56 K+0.70 v)\left(e_{w}-e_{a}\right) 4.19
$$

$Q_{e}$ : Heat Loss by evaporation $\left(\mathrm{W} / \mathrm{m}^{2}\right)$

$e_{w}$ : Partial pressure from vapor on the surface (mbar)

$e_{a}$ : Partial pressure from steam in the air (mbar)

Based on data from http://wisatalembang.com, humidity for the swimming pool area is $70 \%$ and average air temperature is $24^{\circ} \mathrm{C}$. Partial pressure of vapor in the air $\left(e_{a}\right)$ in these conditions is 20.7 millibars and $\left(e_{w}\right)$ can be assumed that there is a marginal layer on surface of pool water with a temperature equal to the temperature of pool water which is $26^{\circ} \mathrm{C}$. Humidity for the marginal layer is assumed to be $100 \%$ so the saturation pressure at that temperature is 33 millibars. Table 9 shows the variation in the value of heat loss due to the evaporation process with a pool temperature between $26^{\circ} \mathrm{C}$ to $30^{\circ} \mathrm{C}$.

Table 9. Variation in value of heat loss caused by evaporation process

\begin{tabular}{lcccccccc}
\hline Qe $\left(\mathrm{W} / \mathrm{m}^{2}\right)$ & $\mathrm{T}_{\mathrm{he}}\left({ }^{\circ} \mathrm{C}\right)$ & $\mathrm{T}_{1}\left({ }^{\circ} \mathrm{C}\right)$ & $\mathrm{T}_{\mathrm{a}}\left({ }^{\circ} \mathrm{C}\right)$ & $\mathrm{K}\left(\mathrm{W} / \mathrm{m}^{20} \mathrm{C}\right)$ & $\mathrm{v}(\mathrm{m} / \mathrm{s})$ & $\mathrm{e}_{\mathrm{w}}$ (millibar) & $\mathrm{e}_{\mathrm{a}}$ (millibar) & $\mathrm{RH}(\%)$ \\
\hline 139.56 & 33.00 & 26.00 & 24.00 & 1.29 & 1.00 & 33.00 & 20.72 & $70 \%$ \\
162.29 & 33.00 & 27.00 & 24.00 & 1.29 & 1.00 & 35.00 & 20.72 & $70 \%$ \\
196.39 & 33.00 & 28.00 & 24.00 & 1.29 & 1.00 & 38.00 & 20.72 & $70 \%$ \\
230.48 & 33.00 & 29.00 & 24.00 & 1.29 & 1.00 & 41.00 & 20.72 & $70 \%$ \\
253.21 & 33.00 & 30.00 & 24.00 & 1.29 & 1.00 & 43.00 & 20.72 & $70 \%$ \\
\hline
\end{tabular}

Total heat loss due to convection and evaporation process can be calculated as follows: 


$$
Q_{\text {total }}=Q_{r}+Q_{e}+S
$$

Qtotal is Total heat in hot spring pool $\left(\mathrm{W} / \mathrm{m}^{2}\right), \mathrm{S}$ is $10 \%$ from $(\mathrm{Qc}+\mathrm{Qe})$ for other sources of heat loss $\left(\mathrm{W} / \mathrm{m}^{2}\right)$.

Table 10. Total heat loss in a heated swimming pool

\begin{tabular}{ccccc}
\hline $\mathrm{Q}_{\text {total }}\left(\mathrm{W} / \mathrm{m}^{2}\right)$ & $\mathrm{Qe}\left(\mathrm{W} / \mathrm{m}^{2}\right)$ & $\mathrm{Qc}(\mathrm{W} / \mathrm{m} 2)$ & $\mathrm{S}\left(\mathrm{W} / \mathrm{m}^{2}\right)$ & $\mathrm{T}_{1}\left({ }^{\circ} \mathrm{C}\right)$ \\
\hline 169.6 & 139.6 & 14.6 & 15.4 & 26.00 \\
202.6 & 162.3 & 21.9 & 18.4 & 27.00 \\
248.1 & 196.4 & 29.2 & 22.6 & 28.00 \\
293.6 & 230.5 & 36.5 & 26.7 & 29.00 \\
326.7 & 253.2 & 43.7 & 29.7 & 30.00 \\
\hline
\end{tabular}

To get the desired temperature $\left(26^{\circ} \mathrm{C}-30^{\circ} \mathrm{C}\right)$ (See Table 10), we must add heat according to the heat lost due to the process described earlier.

$$
Q_{1}=Q_{i}
$$

Qi is total heat needed to heat the pool $\left(\mathrm{W} / \mathrm{m}^{2}\right)$; Value Qi obtained from heat derived from heat exchangers by using the energy equilibrium equation:

$$
Q_{i}=m_{1} C p_{1}\left(T_{2}-T_{1}\right)=m_{2} C p_{2}\left(T_{3}-T_{4}\right)
$$

Where Qi is heat needed to heat the pool $\left(\mathrm{W} / \mathrm{m}^{2}\right), \mathrm{m}_{1}$ is Fluid flow rate to be circulated $(\mathrm{kg} / \mathrm{s}), \mathrm{m}_{2}$ is Geothermal fluid flow rate $(\mathrm{kg} / \mathrm{s}), \mathrm{Cp}_{1}$ is specific heat capacity of water $\left(\mathrm{J} / \mathrm{Kg}^{\circ} \mathrm{C}\right), \mathrm{T}_{1}$ is Pool water temperature at the heat exchanger inlet $\left({ }^{\circ} \mathrm{C}\right), \mathrm{T}_{2}$ is Pool water temperature at the heat exchanger outlet $\left({ }^{\circ} \mathrm{C}\right), \mathrm{T}_{3}$ is Pool water temperature at the heat exchanger outlet $\left({ }^{\circ} \mathrm{C}\right)$, and $\mathrm{T}_{4}$ is Geothermal fluid temperature at the heat exchanger outlet $\left({ }^{\circ} \mathrm{C}\right)$.

\section{Economic Analysis}

\section{Estimated Costs}

The cost calculation is based on 2014 price assumptions with the assumption of a $5 \%$ annual price escalation and an assumption for the USD/IDR 12,900 exchange rate (see Table 11).

Table 11. Specifications for the prices of goods and services for the provision of hot water swimming pools in the Lembang area, West Java

\begin{tabular}{lcc}
\hline \multicolumn{1}{c}{ Types of item and services } & USD & IDR \\
\hline Swimming pool equipment (including plan \& design) & 2,500 & $32,250,000$ \\
Land and building prices in the swimming pool area $\left(2000 \mathrm{~m}^{2}\right)$ & & $1,000,000,000$ \\
\multicolumn{1}{c}{ Swimming pool system } & & \\
Cleansing equipment (1 sand filter merk Jacuzzi) & 651 & $8,397,900$ \\
Heat saving equipment & 250 & $3,225,000$ \\
Circulating pump (Afton pump ILVS series) 3 piece & 1,600 & $20,640,000$ \\
Circulating pump & & $29,700,00$ \\
Inlet and outlet connection to pool & 800 & $10,320,000$ \\
Piping (30 mm and 60 mm) & 43,200 & $6567,280,000$ \\
Piping (stainless steel and fibre glass for 200 m) & & \\
Electricity system & & 900,000 \\
Price of PLN electricity pairs & 450 & $5,805,000$ \\
Control equipment (3 unit) & & $1,400,000$ \\
Cable (100 m) ETERNA NYM 4 x 2.5 & & $2,000,000$ \\
Installation services & Total & $1,672,577,900$ \\
\hline
\end{tabular}




\section{Assumptions for Modelling and Entering Business}

Table 10 has explained the total investment needed to procure a hot water swimming pool in the Lembang area, West Java amounting to $\mathrm{Rp} 1,672,577,900 \approx \mathrm{Rp} 1,700,000,000$. In this study, the capital owner is assumed to only have a fund of $\mathrm{Rp} 1,000,000,000$ so that additional capital is needed from a bank loan of $\mathrm{Rp} 700,000,000$ with current bank interest of $12 \%$. Business income is obtained from entry tickets for adult and children visitors with the following detailed explanation (Table 12).

Table 12. Estimated entry ticket price

\begin{tabular}{ccc}
\hline Ticket & Weekdays & Weekends \\
\hline Children & $20,000 \mathrm{IDR}$ & $25,000 \mathrm{IDR}$ \\
Adult & $25,000 \mathrm{IDR}$ & $30,000 \mathrm{IDR}$
\end{tabular}

Based on BPS data in 2013 each year foreign tourists coming to the city of Bandung increased by $26 \%$ and in 2012 the number of foreign tourists who came as many as 148,445 people. Tourists dominated by neighbouring tourists such as Malaysia, Singapore, and Thailand. This fact is basis of assumption of the number of tourists coming to Lembang area, West Java because this location is a tourist destination.

The number of visitors to heated swimming pool every day is assumed as many as 50 people consisting of 40 adults and 10 children and for weekend it is expected that the number of visitors will be 75 people consisting of 60 adults and 15 children. Average pool turnover in one year based on this calculation is Rp. $550,000,000$. Operating and maintenance costs come from electricity usage costs and employee salaries with a total cost of Rp. 31,000,000/month. It is also assumed that there is a price escalation for a turnover increase of $2 \%$ t $/$ year.

\section{Project Feasibility Analysis}

There are several parameters that determine the feasibility of project being carried out. The parameters commonly used are IRR (Investment Rate of Return) and NPV (Net Present Value). IRR is a parameter that shows there is a profit from investing funds into a project, calculated on the initial outlay on the basis of cash flows in future periods. NPV $>1$ indicates the value of this project in the future can be assumed feasible or not.

The payback period was also calculated as the ratio between the initial investment and the cash flows. Clearly, the lower the value of the payback the lower the investment risk since it would require less time to recover the money invested.

Based on the NPV calculation for this hot water pool development project, Rp 126,421,602 and IRR of $17 \%$ with the payback period 10.02 years. This fact shows that from an economic standpoint this activity is interesting to do.

\section{CONCLUSION}

Based on the results of studies conducted from the perspective of the principle of engineering and economic analysis it can be concluded that heat energy needed to maintain a hot water pool at a temperature of 26 ${ }^{\circ} \mathrm{C}-30{ }^{\circ} \mathrm{C}$ is 170 to $330 \mathrm{~W} / \mathrm{m}^{2}$. It takes several components in a hot water pool system such as heat exchangers, circulating pumps, filter plants, and chemical tanks that maintain the cleanliness of a heated swimming pool. The type of pipe material used for this system is PVC pipe with a diameter variation of $30-60 \mathrm{~mm}$. Economically, a hot water pool development project with an NPV of more than 1 and an IRR of $17 \%$ for a 10 -year economic period.

\section{Acknowledgements}

This research is supported by Lembaga Penelitian dan Pengabdian Kepada Masyarakat (LPPM) Universitas Pembangunan Nasional Veteran Yogyakarta (Grant No: B/519/UN.62/PT/X/2019).

\section{References}

Ahmed, T. (2018). Reservoir engineering handbook. In Reservoir Engineering Handbook (5th ed.). Elsevier. https://doi.org/10.1016/C2016-0-04718-6

Barbato, M., Cirillo, L., Menditto, L., Moretti, R., \& Nardini, S. (2018). Feasibility study of a geothermal energy system for indoor swimming pool in Campi Flegrei area. Thermal Science and Engineering Progress, 6, 421-425. https://doi.org/10.1016/j.tsep.2018.02.013

BPPT. (2004). TEKNOLOGI PEMANFAATAN ENERGI PROYEK PENGKAJIAN DAN PENERAPAN 


\section{TEKNOLOGI ENERGI.}

Carter, R. D., \& Tracy, G. W. (1960). An Improved Method for Calculating Water Influx. Transactions of the AIME, 219(01), 415-417. https://doi.org/10.2118/1626-g

Darma, S. (2016). Indonesia: Vast geothermal potential, modest but growing exploitation. In R. DiPippo (Ed.), Geothermal Power Generation: Developments and Innovation (pp. 609-643). Elsevier Inc. https://doi.org/10.1016/B978-0-08-100337-4.00021-8

Engineering ToolBox. (2003). PE, PEH or PVC Pipes - Pressure Drop Diagram. https://www.engineeringtoolbox.com/peh-pvc-pipes-pressure-drop-d_317.html

Fahmy, F. H., Farghally, H. M., \& Ahmed, N. M. (2014). Swimming pool system based on geothermal energy in Egypt. Journal of Next Generation Information Technology, 5(1), 27-40.

Holman, J. P., \& Rao, P. . (1989). Heat Transfer. McGraw-Hill Education.

Jacuzzi. (2005). Laser Sand Filter System. https://images.inyopools.com/cloud/documents/jacuzzi-pumpfilter-laser-sand.pdf

Jalili Nasrabadi, S. (2004). Geothermal District Heating and Swimming Pool in the Sabalan Area, Iran.

Jalilinasrabady, S., Itoi, R., \& Ohya, Y. (2015). Hybrid Geothermal and wind power generation system using geothermal waste water as a heat source. Proceedings, World Geothermal Congress, 19-25.

Omotayo Adewale, O., \& Sunday, I. (2015). Aquifer Detection and Characterisation Using Material Balance: A Case Study of Reservoirs A, B, C and D. International Journal of Science, Technology and Society, 3(2), 64. https://doi.org/10.11648/j.ijsts.20150302.14

Orkustofnun. (2020). Bathing \& recreation / Direct Utilization / Geothermal / National Energy Authority of Iceland. National Energy Authority. https://nea.is/geothermal/direct-utilization/bathing-recreation

Svavarsson, G. (1990). Designing swimming pools. University of Iceland.

Van Everdingen, A. F., \& Hurst, W. (1949). The Application of the Laplace Transformation to Flow Problems in Reservoirs. Journal of Petroleum Technology, 1(12), 305-324. https://doi.org/10.2118/949305-g 